\title{
FIRST RECORD OF THE EASTERN PHOEBE BREEDING IN ALASKA: EXTRALIMITAL BY 2000 KM
}

\author{
BRYCEW. ROBINSON, 615 East Krall St., Boise, Idaho 83712; bryce@ornithologi.com \\ LUCAS H. DECICCO, 4826 Mills Drive, Anchorage, Alaska 99508 \\ AARON BOWMAN, 1008 W 30th Ave \#3, Anchorage, Alaska 99503 \\ SCOTT HAUSER, 12900 Saunders Road, Anchorage, Alaska 99516 \\ JOHN M. WRIGHT, 1991 St Bernard Dr., Fairbanks, Alaska 99709
}

The Eastern Phoebe (Sayornis phoebe) nests across much of North America east of the Rocky Mountains (Sinclair et al. 2003, Van Damme 2010, Weeks 2011). Although Alberta represents the western extreme of the species' regular breeding distribution, extralimital nesting occasionally occurs west to southeastern Yukon Territory and northeastern British Columbia (Sinclair et al. 2003, Van Damme 2010). In Alaska, the Eastern Phoebe is a casual visitor with no previous nesting records (see Gibson and Withrow 2015; Table 1). Here we document the first record of the Eastern Phoebe nesting in the state of Alaska, the westernmost breeding record for the species and extralimital by $2000 \mathrm{~km}$.

On 5 June 2016, a University of Alaska Fairbanks Summer Session birding party led by Wright found a single Eastern Phoebe frequently flying in and out of an abandoned aluminum camper trailer west of the Hastings Creek crossing of the Nome-Council Road on the Seward Peninsula, western Alaska. Wright investigated the inside of the trailer but found no signs of nesting. On 7 June, a Wilderness Birding Adventures group led by Bowman and Hauser independently reported an Eastern Phoebe in the driftwood along Hastings Creek. At the time, Bowman noted the bird repeatedly carrying nest material into a drainage culvert running north-south under the Nome-Council road, but after investigation found no nest structure. Birders continued to report a single Eastern Phoebe until 9 June when two birds were building a nest, again in the drainage culvert (B. Benter pers. comm.). The nest was $\sim 3$ m inside the culvert $\left(64^{\circ} 27^{\prime} 21^{\prime \prime} \mathrm{N}, 165^{\circ} 5^{\prime} 45^{\prime \prime} \mathrm{W}\right)$, only $0.5 \mathrm{~km}$ from the coast of the Bering Sea. The nest structure was built on top of piping suspended $\sim 0.25 \mathrm{~m}$ from the top of the culvert, was constructed primarily of mud, grass, moss, and lichen, and was lined with grass and qiviut (wool of the muskox, Ovibos moschatus; Figure 1).

It is unclear when eggs were laid or incubation began, but on 15 June Paul E. Lehman found a broken egg beneath the nest (remains to San Diego Natural History Museum). On 21 July Robinson observed and photographed nestlings (Figure 1). In late July, Robinson and DeCicco checked the nest frequently to determine its fate. Fledglings were first observed and photographed on 23 July (K. Persons in litt.), then on the $25^{\text {th }}$ Robinson and DeCicco observed at least three fledged young (Figure 2) being fed by at least one adult in willows along the eastern edge of Hastings Creek. Despite searches of the area, the birds were not observed after 25 July. This, the first case of the Eastern Phoebe nesting in Alaska, is especially notable given this pair's ability to successfully fledge young $2000 \mathrm{~km}$ from the species' normal breeding range. It is unlikely that a pair of Eastern Phoebe could have nested in the coastal tundra zone of Alaska without the presence of human-made structures, such as the culvert.

The Eastern Phoebe is considered hardy in general and flexible in its diet (Weeks 2011). It often returns to its breeding range as early as March (Bent 1942, Weeks 2011), and it has been documented consuming fish (Jung 1926, Binford 1957) and fruits (Bent 1942, Graber et al. 1974) when insects are scarce, unlike most other North American flycatchers, which are exclusively insectivorous during the breeding season (Murphy 1987, Teather 1992, Troy and Baccus 2009). These factors may have contributed to the pair's ability to breed successfully at Nome. Additionally, the 


\section{NOTES}

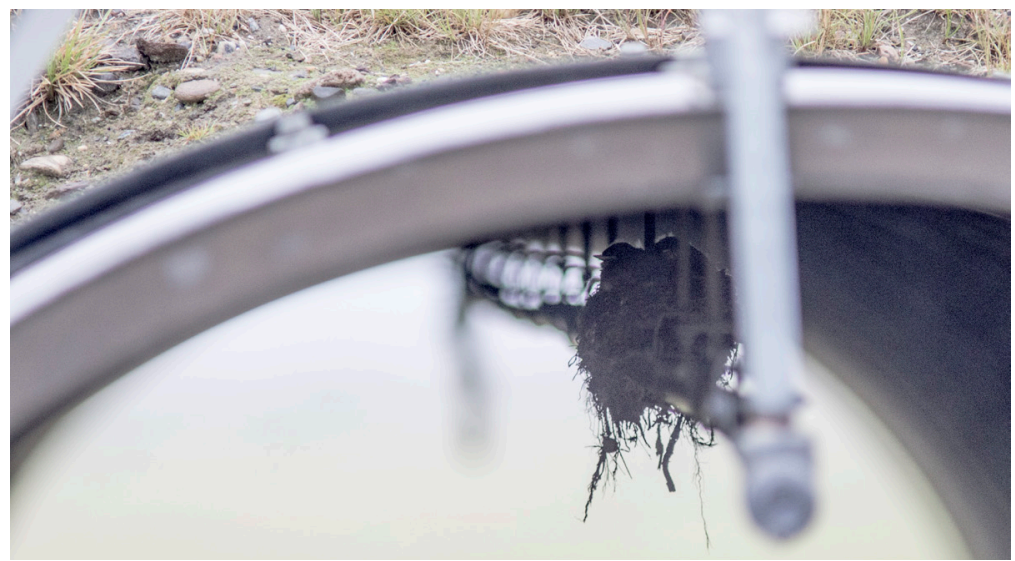

Figure 1. Eastern Phoebe nest in a culvert under the Nome-Council Road on the Seward Peninsula, Alaska, 21 July 2016.

Photo by Bryce W. Robinson/USFWS

congeneric Say's Phoebe (S. saya) also nests on the Seward Peninsula beyond the limit of boreal forest (Schukman and Wolf 1998), suggesting together with this breeding of the Eastern Phoebe, that members of this genus may occupy an ecological niche more flexible or broader than do many other tyrannids.

The Eastern Phoebe is socially monogamous, with high fidelity to a nest site and mate, and it regularly rebuilds and reuses nest structures in the same territory in successive years (Greenwood and Harvey 1982, Beheler et al. 2003). Given these tendencies, it is just possible that this pair may return to Nome. Anticipating their reuse of the nest site and regularly checking for their presence may provide remarkable detail to an already remarkable nesting record.

We thank everyone who submitted their Nome Eastern Phoebe sightings to www. eBird.org. Constructive reviews of the manuscript provided by Daniel D. Gibson, Steven C. Heinl, Daniel R. Ruthrauff, and Jack J. Withrow are greatly appreciated.

Table 1 Alaska Records of the Eastern Phoebe

\begin{tabular}{lccc}
\hline Date & Observation & Location; region $^{a}$ & Reference $^{b}$ \\
\hline 26 Jun-6 Jul 1990 & singing male & Camden Bay; N & AB 44:1172 \\
21 Jun 1993 & one & Hyder; SE & AB 47:1140 \\
18 Jun 1995 & singing male & Mitkof Is.; SE & FN 49:965 \\
11 May 2007 & singing male & Haines; SE & NAB 61:496 \\
13 Aug 2009 & one & Chitina River headwaters; S-C & B. Benter pers. comm. \\
20 Jun 2013 & singing male & Yakutat; SE & NAB 67:639 \\
25 May 2015 & one & Utqiagvik (Barrow); N & NAB 69:468 \\
2 Jun 2015 & singing male & Yakutat; SE & NAB 69:470 \\
14-16 Jun 2015 & singing male & Nabesna Rd. 7 km E of Glenn & C. Mclntyre in litt. \\
& & Hwy.; S-C & \\
5 Jun-25 Jul 2016 & nesting pair & 15 km ESE of Nome; W & pers. obs. \\
\hline
\end{tabular}

${ }^{a}$ As outlined by Gibson and Withrow (2015): N, northern; S-C, south-central; SE, southeastern; W, western. ${ }^{b} \mathrm{AB}$, American Birds; FN, National Audubon Society Field Notes; NAB, North American Birds. cSpecimen; University of Alaska Museum 6711. 


\section{NOTES}

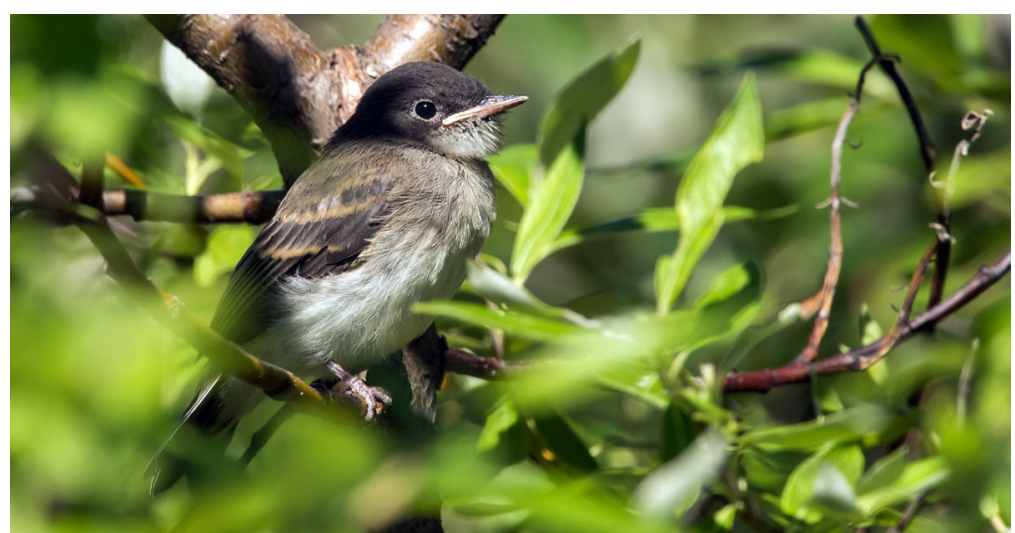

Figure 2. Fledgling Eastern Phoebe, one of at least three successfully fledged young present in willow thickets in the Hastings Creek area on the Seward Peninsula, Alaska, on 25 July 2016.

Photo by Lucas H. DeCicco/USFWS

\section{LITERATURE CITED}

Beheler, A. S., Rhodes, O. E. Jr., and Weeks, H. P. Jr. 2003. Breeding site and mate fidelity in Eastern Phoebes (Sayornis phoebe) in Indiana. Auk 120:990-999.

Bent, A. C. 1942. Life histories of North American flycatchers, larks, swallows, and their allies. U.S. Natl. Mus. Bull. 179.

Binford, L. C. 1957. Eastern Phoebes fishing. Auk 74:264-265; doi 10.2307/4081726.

Gibson, D. D., and Withrow, J. J. 2015. Inventory of the species and subspecies of Alaska birds, second edition. W. Birds 46:94-185.

Graber, R. R., Graber, J. W., and Kirk, E. L. 1974. Illinois birds: Tyrannidae. Ill. Nat. Hist. Surv. Biol. Notes 86.

Greenwood, P. J., and Harvey, P. H. 1982. The natal and breeding dispersal of birds. Annu. Rev. Ecol. Syst. 13:1-21; doi 10.1146/annurev.es.13.110182.000245.

Jung, C. S. 1926. The season. Chicago region. Bird-Lore 28:63-64.

Murphy, M. T. 1987. The impact of weather on kingbird foraging behavior. Condor 89:721-730; doi 10.2307/1368518.

Schukman, J. M., and Wolf, B. O. 1998. Say's Phoebe (Sayornis saya), in The Birds of North America (A. Poole and F. Gill, eds.), no. 374. Birds N. Am., Philadelphia; doi 10.2173/bna.374.

Sinclair, P. H., Nixon, W. A., Eckert, C. D., and Hughes, N. L. (eds.). 2003. Birds of the Yukon Territory. Univ. Br. Columbia Press, Vancouver.

Teather, K. 1992. Foraging patterns of male and female Scissor-tailed Flycatchers. J. Field Ornithol. 63:318-323.

Troy, J., and Baccus, J. 2009. Effects of weather and habitat on foraging behavior of nonbreeding Eastern Phoebes. Wilson J. Ornithol. 121:97-103; doi 10.1676.07-175.1.

Van Damme, L. M. 2010. Extra-limital breeding record for Eastern Phoebe in the Creston Valley, British Columbia. Wildlife Afield 7:289-291.

Weeks, H. P. Jr. 2011. Eastern Phoebe (Sayornis phoebe), in The Birds of North America Online (P. G. Rodewald, ed.), no. 94. Cornell Lab Ornithol., Ithaca, NY; doi 10.2173/bna.94. 